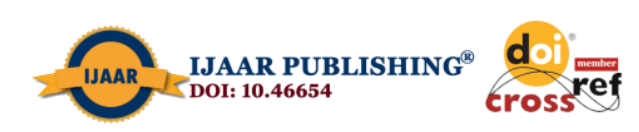

International Journal of Advanced Academic Research | ISSN: 2488-9849

Vol. 7, Issue 5 (May, 2021) | www.ijaar.org

Journal DOI: www.doi.org/10.46654/ij.24889849

Article DOI: www.doi.org/10.46654/ij.24889849.s7597

\title{
YOUTH INVOLVEMENT IN PARAMILITARY BODIES: A CASE STUDY OF THE ROYAL SHEPHERDS OF CHRIST APOSTOLIC CHURCH IN NIGERIA, 2002-2021
}

\author{
Afolabi Samuel Oluseyi, Ph.D. \\ Email: samseyiafolabi@gmail.com \\ Telephone: +234803 4127021

\section{Biographical Sketch of the Author}

AFOLABI, Samuel Oluseyi holds a Ph.D. in Religious Studies from the University of Ibadan, Nigeria. He is a Lecturer in Church History, Church Planting and Growth at Michael Olowere College of Theology (MOCOT), Ashi, Ibadan, Oyo State, Nigeria.

$\mathrm{He}$ is an alumnus and a lecturer of Missions and Exposure Training - MET (Pentecostal Assemblies of Canada), Pretoria, South Africa.

He is the Senior Pastor of Christ Apostolic Church All Nations Assemblies, Ibadan, Nigeria.

\begin{abstract}
Christ Apostolic Church is a foremost African Indigenous Church which has proliferated and shown phenomenal growth particularly in Nigeria. One of the factors responsible for the growth and expansion of the church in Nigeria was the activities of its youth organisations among which is the Royal Shepherds. This article focuses on the Royal Shepherds which is the paramilitary outfit of Christ Apostolic Church in Nigeria. The research highlights the history of the organisation, its aims and objectives and its administration. It also features the programmes and activities of the organisation and gives detailed attention to the specific contributions of the organisation to the growth of Christ Apostolic Church in Nigeria. Data were gathered through the use of structured oral interview, archival materials and bibliographical search. Useful suggestions were offered to improve the operations of the organisation.
\end{abstract}

Keywords: Christ Apostolic Church, Paramilitary, Youths, Growth and Expansion. 
Journal DOI: www.doi.org/10.46654/ij.24889849

Article DOI: www.doi.org/10.46654/ij.24889849.s7597

\section{Introduction}

It is a universally accepted truism that many youths usually prefer to associate with various youth clubs which offer different appeals such as uniform wearing, and which is regimental or para-military in nature. Such uniformed groups provide added advantages of instant recognition, authority and respect in the society. This explains why many Christian youths usually register as members of NGO's such as Boys' Brigade, Girls' Brigade, Boy Scouts, Girl Guides, Man O' War, WAI Brigade, etc. and this also explains why many other Churches in Nigeria have established or integrated various types of disciplined, regimental and para-military voluntary youth movements into their congregations. ${ }^{1}$

Modern uniformed youth groups first appeared in the late-19th century as social leaders attempted to channel the energies of young people in the new developing industrial economies of Europe and America. Crime was increasing and centuries old social restraints were crumbling while in response, Government and community leaders pondered what to do. The answer was the formation of youth groups to channel the boundless energies of the young people in the new industrial societies of Western Europe. The Church was the motivating institution behind the first group with the formation of the Boys' Brigade in Glasgow in 1883. Other groups later came up. All of these new groups were uniformed groups and their purpose was to mould and channel the energies of young people while regimentation was seen as an important element in that process. ${ }^{2}$

Following the above pattern, the Authorities of Christ Apostolic Church Nigeria, at the meeting of the General Executive Council held at Ikeji Arakeji Camp on Wednesday, $10^{\text {th }}$ May, 2002, unanimously resolved to establish a distinct voluntary youth wing for the church, following the initiative of the then serving President (now late President), Pastor E.H.L. Olusheye. With due reference to the Nigerian Constitution on the formation and inauguration of youth chapters at various levels, the Authorities of C.A.C in compliance with the Act of Parliament $25^{\text {th }}$ August, 1964, and as amended through the National Youth Policy of 2001, decided to form this youth organization. The body which is a uniformed one is christened, "Royal Shepherds". ${ }^{3}$ The body is also known as "Christ's Warriors". " The organisation has some branches at District, DCC and State levels of the church in Nigeria.

\section{Why the Use a Uniform?}

The wearing of a uniform encourages a sense of community, group identity and esprit de corps as members are identifiable as part of something big. It also acts as a 'leveller' in that all are equal, regardless of the family's socio-economic situation. The uniform is designed to teach each person to have pride in themselves and their appearance from an early age. ${ }^{5}$

\section{The Aims and Objectives of the Royal Shepherds}

1. The primary aim of this youth organization is character development; to make all youths become 'born again' disciples of Christ and good citizens.

2. This aim shall be achieved by:

i. Teaching members the need for a sound knowledge of the Word of God.

ii. Making members lead truly prayerful lives that are committed to private, regular and incessant prayer lives.

iii. Inculcating in every member the need to receive, possess and maintain the Holy Spirit of God, including spiritual gifts, fruit and power as enjoyed by the early Christians. 
Journal DOI: www.doi.org/10.46654/ij.24889849

iv. Encouraging members towards steadfast love, honesty, chastity, deeply spiritual and holy lives and being worthy ambassadors of Christ at all times.

v. Training members in the principle and methods of evangelism and soul winning and also making them to go and convert non-Christians by all peaceful and persuasive means as Christ's witness.

vi. Encouraging members towards good citizenship, self-reliance, resourcefulness, obedience, loyalty, mental alertness and thoughtfulness for others.

vii. Promoting their physical development, training them in services useful to the public, handicrafts and professional skills useful to themselves. ${ }^{6}$

\section{The Administration of the Royal Shepherds}

The Royal Shepherds exist in the Church at the National level, State level, Division (Township) level, Battalion level (Districts Coordinating Council), District Headquarters and Company level (Local Assemblies).

The officers at the National level are the National Director, the Deputy National Director, the National Organizing Secretary, National Legal Adviser, National Finance Officer, National Treasurer, Public Relations Officer, National Project Officer and National Internal Auditor. ${ }^{7}$ At the State level the coordinating officers are: the State Commandant, Deputy Commandant, Secretary, Training officer, Welfare officer, Public Relations officer and Disciplinary officer.

At the Division (Township) Council, the officers comprise the Divisional Commandant, Deputy Commandant, Secretary, Training officer and Welfare officer, while the coordinating officers at the Battalion (Districts Coordinating Council and Assembly) levels are: the Battalion Coordinator, Assistant Battalion Coordinator, Secretary, Training officer and Welfare officer. The officers at the Company level are Captain, Male Lieutenants, Female Lieutenants, Secretary, Treasurer and Chaplain. ${ }^{8}$

\section{The Programmes and Activities of the Royal Shepherds.}

Various programmes such as leadership trainings and spiritual retreats are organized for members at all the above levels. There are different training courses such as Officers' Basic Training (for Basics 1, 2 and 3), Advance Training Course and the Leaders Trainers' Course. ${ }^{9}$ The yearly calendar of the organization also includes:
a. Annual Anniversary service
b. Annual Rally
c. Outside visits /Excursions
d. Campaigns
e. Special Seminars
f. Parents' night
g. Games/sports

The weekly, monthly, and periodic meetings are fixed as deemed fit by the leadership at the various levels.

\section{Funding}

The organization is being funded at different levels mainly from the purse of the local Assemblies where each battalion belongs to. The Patrons and Patronesses and other elderly officers appointed for the group also carry a great part of the financial burden of the group. In 
Journal DOI: www.doi.org/10.46654/ij.24889849

Article DOI: www.doi.org/10.46654/ij.24889849.s7597

addition, the group generates money from levies paid by members, appeal letters written to people and the freewill donations given by church members during their annual anniversaries (Annual Enrolment). ${ }^{10}$

\section{The Contributions of the Royal Shepherds to C.A.C}

\section{Para-Military Services}

The major contribution of the organization to C.A.C is in the area of para-military services which include security, crowd control and road safety.

\section{Security}

The organization, being a uniformed one, with members who have been trained in enforcement of security has always helped to maintain adequate security and peace in the church during worship services and evangelistic/open air crusades. During such services, the members help to protect vehicles, church properties and other personal effects of worshippers. Their presence helps to ward off miscreants and pick pockets who aim at attacking worshippers. The organization has also been of help in providing security for church offerings/collections, especially during evangelistic and open-air crusades where crowds were in attendance. ${ }^{11}$

\section{Crowd and Traffic Control}

The Royal Shepherds have also been of help to the church in the area of crowd and vehicle control. They have helped to maintain orderliness and calmness at programme venues and among the crowd during periods of worship that attracted large crowd and many vehicles.

They also ensured that there were no blockages on the roads adjoining the programme venues in order to create easy passage for other road users. Instead of the usual rowdiness and chaos that often characterized such programmes, the presence of members of the organization made room for easy flow of traffic and people. This has also helped to prevent road accidents and other associated hazards during church programmes. ${ }^{12}$

\section{Proclamation of the Gospel/Publicity}

The organization performs this role by sending out its members periodically to engage in distribution of gospel tracts and flyers on the streets and from house to house. They go along with their sets of drums and musical instruments, supplying gospel music as they go about distributing the tracts. In so doing they are advancing Christ's Kingdom in their local communities. This has helped in no small way to proclaim the Gospel and also bring in new members to the local Assemblies in Christ Apostolic Church. ${ }^{13}$

\section{Ceremonial Functions}

The group also plays active part in the Church's ceremonial functions like Annual Conventions, Church Anniversaries, Men and Women Anniversaries, Choir Anniversaries, etc. During such programmes, members of the Royal Shepherds are always on ground to add beauty to the occasions by providing good music with their musical band; and ushering the officiating ministers in and out of the programme venue with military salutations. This usually adds colour and glamour to these occasions and it is always a special delight of worshippers and participants in the programmes. ${ }^{14}$ 
Journal DOI: www.doi.org/10.46654/ij.24889849

\section{Spiritual and Character Development of Youths}

The trained leaders of the group are utilising the programmes as a tool to instill spiritual and character development into the young ones. They are being trained to develop sound knowledge of the Word of God, to be committed to private, regular and incessant prayer lives, to develop steadfast love, honesty, chastity, deeply spiritual and holy lives and being worthy ambassadors of Christ at all times. The paramilitary drills are also tailored to instill the value of discipline and mentor each person in their journey towards faith, and subsequently towards Christian maturity. The ultimate goal of this training is to prepare the young ones to take up leadership positions later in the Church. This is already yielding positive results as we now have former members of the organization as ordained Pastors, Evangelists and leaders of various units in the Church. ${ }^{15}$

\section{A Major Challenge to The Organisation}

While the Royal Shepherds have been actively involved in contributing to the growth of Christ Apostolic Church in Nigeria, their operations have been confronted with diverse problems which have stood as hindrances to their effectiveness over the years. A major challenge in this regard is that of poor financing.

Few issues are as pertinent for the contemporary church as the issue of financial stewardship. Simply put, organisations need resources, especially financial resources. Without income, no organisation can maintain its facilities, staff, or substantial programs. ${ }^{16}$

The fact that majority of youths who are members of the organisation are students in secondary and higher institutions and they depend on their parents for finances have greatly limited the financial capability of the organisation in their bid to carry out their lofty programmes. Many times, the organisation depends mainly on the church for all their finances thereby making it difficult to get money from the church Authority to organise their programmes. The board of elders/church committee in some C.A.C Assemblies usually allocate small amount of money for the Royal Shepherds in the Church's budget and it is usually meager where such exists. ${ }^{17}$

The expected free-will donations and offerings from members and philanthropists never come on most occasions; the reason being that, the Church authority seldom mobilises wealthy members of the Church to support the programmes of youth organisations due to cases of unhealthy rivalries between youths and church authority.

In the course of this research, many of the interview respondents agreed that the problem of poor financing has hindered the maximum performance of the organization. ${ }^{18}$

Some of the Royal Shepherds' leaders are at times frustrated when the subvention from the church is not released on time. This problem of inadequate funding has greatly affected the organisation, scope, expansion and effectiveness of their programmes. Many of their activities like trainings and workshops, outside visits /excursions, campaigns, games/sports, annual anniversary service, annual rally, etc. are either poorly organised or postponed indefinitely because of insufficient funds. ${ }^{19}$ Many of such programmes which could have enhanced career and capacity building among members of the organisation have greatly suffered setback due to lack of funds. 
Journal DOI: www.doi.org/10.46654/ij.24889849

Article DOI: www.doi.org/10.46654/ij.24889849.s7597

Poor financing has also made it impossible to procure essential equipment like modern sets of drums, musical instruments and decent uniforms the organisation while it also becomes difficult to take care of indigent members who need financial support for personal upkeep or for their schooling.

As a panacea to this menace, we hereby suggest that the authorities and leaders of the church should be ready to invest good amount of money in the Royal Shepherds as a way of encouraging and motivating the youths. The church at various levels should have a good annual budget for this group. The church leaders should come up with some other methods or strategies whereby wealthy people in the church can be convinced to make special financial donations towards the funding of the group.

\section{Conclusion}

Youths constitute a vitally important segment of the society. In every culture they symbolise continuity and because of their important place in the society, they have always been highly esteemed. ${ }^{20}$ While some people see them as uncontrollable and ungovernable due to lack of understanding on the part of such people, the contributions of these youths have shown to a large extent that they do not mean to destroy the church, rather they sought to promote and lift her to an enviable position among other churches.

The youth ministry is essential. The things they can do, the places they can go and the impacts they can make are enormous. Their ministry builds the church, reaches the lost, and enhances the continuity of the church. ${ }^{21}$ Youths should be encouraged to operate in the church without suspicion and their vision/programmes should be embraced by the leadership of the church. Church leaders must have a positive and respectful view of young people in order to engage them meaningfully for church growth. Negative views of young people tend to limit their opportunities to participate actively in activities that promote church growth and expansion. Church leaders should rather accept and nurture them gradually to greater heights in life. 


\section{ENDNOTES}

${ }^{1}$ C.A.C, 2003 Royal Shepherds Handbook of Policy, Organization and Rules. Lagos: C.A.C General Executive Council, p1.

${ }^{2}$ Historical Boys' Clothing (2003) Scout and Other Uniformed Youth Groups. https://www.histclo.com/youth/youth.html accessed on 21st may 2021.

3Ibid

${ }^{4}$ Daniel Moses (Pastor) Interview Respondent, Battalion Commander, Royal Shepherds. Interviewed on 30/03/2021 at C.A.C. Power House, Olodo, Ibadan, Oyo State.

5 The Boys Brigade Australia (2021) Boys' Brigade in Your Church https://boysbrigadeaustralia.org/information-for-churches/5-information-for-churches accessed on 21 st may 2021.

${ }^{6}$ Ibid

${ }^{7}$ Ibid

${ }^{8}$ Tope Ayepada (Prince), Interview Respondent, Asst. National Organizing Secretary, Royal Shepherds. Interviewed on 05/05/14 at C.A.C General Secretariat, Anlugbua, Basorun, Ibadan, Oyo State.

9 Tope Adeyemo (Pastor), Interview Respondent, National Organizing Secretary, Royal Shepherds. Interviewed on 05/05/14 at C.A.C. General Secretariat, Anlugbua, Basorun, Ibadan, Oyo State.

${ }^{10}$ Daniel Moses (Pastor) Interview Respondent, Battalion Commander, Royal Shepherds. Interviewed on 30/03/2021 at C.A.C. Power House, Olodo, Ibadan, Oyo State.

${ }^{11}$ Tope Ayepada (Prince), Interview Respondent, Asst. National Organizing Secretary, Royal Shepherds. Interviewed on 05/05/14 at C.A.C General Secretariat, Anlugbua, Basorun, Ibadan, Oyo State.

12 Tope Adeyemo (Pastor), Interview Respondent, National Organizing Secretary, Royal Shepherds. Interviewed on 05/05/14 at C.A.C. General Secretariat, Anlugbua, Basorun, Ibadan, Oyo State.

${ }^{13}$ Captain Adebisi Racheal Aweda. Interview Respondent, Battalion Commander, Royal Shepherds. Interviewed on 15/04/2021 at Iropora Ekiti, Ekiti State.

${ }^{14}$ Daniel Moses (Pastor) Interview Respondent, Battalion Commander, Royal Shepherds. Interviewed on 30/03/2021 at C.A.C. Power House, Olodo, Ibadan, Oyo State.

15 Ibid

${ }_{16}$ M. M. Mattison. "Church and Money". http://www.auburn.edu/ allenkc/openhse/money.html. Retrieved on 24th April, 2015.

${ }^{17}$ T. A. Agunlejika. 2003. "Evaluating Youth Ministry in Christ Apostolic Church (Osogbo Districts Coordinating Council as a Case Study)". A Long Essay Submitted to ECWA Theological Seminary, Igbaja, 42-43. 
${ }^{18}$ Tope Ayepada (Prince), Interview Respondent, Asst. National Organizing Secretary, Royal Shepherds. Interviewed on 05/05/14 at C.A.C General Secretariat, Anlugbua, Basorun, Ibadan, Oyo State.

Daniel Moses (Pastor) Interview Respondent, Battalion Commander, Royal Shepherds. Interviewed on 30/03/2021 at C.A.C. Power House, Olodo, Ibadan, Oyo State.

Captain Adebisi Racheal Aweda. Interview Respondent, Battalion Commander, Royal Shepherds. Interviewed on 15/04/2021 at Iropora Ekiti, Ekiti State.

${ }^{19}$ Ibid

${ }^{16}$ O. E. Alana. 2011. "Jesus' Teaching on Children and Youths in the Synoptic Gospels". In S. O. Abogunrin (ed.) Biblical Studies and Youth Development in Africa. Ibadan: NABIS. 192.

${ }^{21}$ O. Ademola. "The Youths in Nation Building: A Case Study of Nigerian Baptist Convention Youth Organisations" (M.A Dissertation, Department of Religious Studies, University of Ibadan. 1994), 5. 